\title{
Prepubic tendon rupture in Santa Inês ewe - case report
}

Received: jul, 2020; Accepted: aug, 2020

\author{
Fábia Fernanda Cardoso de Barros da Conceição ${ }^{1^{*}}$, Laís Maria Viana ${ }^{1}$, \\ Franciele de Sá Alves ${ }^{1}$, Marina Resgala Neves ${ }^{1}$, \\ Adriana de Souza Coutinho ${ }^{1}$, Hugo Shisei Toma ${ }^{1}$
}

\begin{abstract}
Prepubic tendon rupture may lead to the loss of pelvic floor support. A four-year-old Santa Inês ewe had been reported suffering from apathy, progressive weight loss throughout ten days, and prolonged pregnancy. Physical exams showed an excessive pendulous abdomen, a mild ventral edema between the udder and the umbilical scar (xiphoid region). Also, the udder was cranially displaced and with hematomas. Other symptoms noticed were walking reluctance, pelvic asymmetry, tachycardia, and tachypnea. The urinalysis findings indicated the presence of ketone bodies. The ultrasound examination confirmed the presence of fetuses with normal development, and a potential rupture of the abdominal muscles was excluded. Eight days following its hospitalization, labor induction was carried out using dexamethasone (20mg, IM, single application). She went into labor three days after the initial dose of corticosteroid. The ewe had difficulty expelling the lambs, making their traction necessary. Although the animal has recovered from its injuries, the clinical picture shows prepubic tendon rupture, and in order to prevent future complications, the ewe is not going to breed anymore. The report of this case works as an alert to the possibility of the occurrence of this affection in ewes and demonstrates the need of parturition assistance in animals with this condition, which can be diagnosed through clinical evaluation and ultrasound examination.
\end{abstract}

Keywords: Ewe, Obstetrics, Gestation, Prepubic tendon rupture.

\section{Introduction}

The prepubic tendon is essentially the tendon of insertion of the abdominal muscles and linea alba. It assists in the action of abdominal

\footnotetext{
${ }^{1}$ Universidade Federal de Lavras, Lavras/ MG, Brasil.

"corresponding author: Condomínio Residencial Sobradinho m. c. 03 DF $150 \mathrm{Km} \mathrm{4,} \mathrm{Setor} \mathrm{habitacional}$ contagem, Sobradinho/ DF; Telefone: (35) 99263-1090; E-mail: fabiafernandavet@gmail.com
} 
contraction, allowing the acts of urination, defecation and birth (BEITTENMILLER; CONSTANTINESCU, 2009). Its rupture is an important obstetric clinical case. The reason for its rupture is uncertain and is usually associated with hydroallantois, pregnancy traumatism, twin pregnancy, and fetal gigantism (PERKINS; FRAZER, 1994). It is most common in mares and it is generally known as a sickness of pregnant mares (JALIM, 2019).

The clinical signs include increased abdominal girth, limiting thus, and an impact on the animal's ability to move (DAR et al., 2016; GYAN et al., 2014). There may be elevation of ischiatic tuberculosis and lordosis (MONTEIRO et al., 2018; DAR et al., 2016; GYAN et al., 2014). The diagnosis is usually based on physical exam, x-ray and abdominal ultrasound (BEITTENMILLER; CONSTANTINESCU, 2009).

The objective of this assignment is to describe the main clinical and pathological findings in a Santa Inês ewe with prepubic tendon rupture and to observe the correlations described in others species' findings.

\section{Case report}

A pregnant four-year-old Santa Inês ewe was assisted at the Large Animal Veterinary Hospital of the Lavras Federal University (UFLA), showing symptoms of apathy, progressive weight loss throughout ten days and prolonged pregnancy. An anamnesis and a physical exam were carried out and, based on clinical signs, further exams (hemogram, urinalysis, and an ultrasound examination) were requested to diagnose and treat its condition.

Physical exam showed an excessive pendulous abdomen, a mild ventral edema between the udder and the umbilical scar (xiphoid region). Also, the udder was cranially displaced and with hematomas. Walking reluctance, pelvic asymmetry, (Figure 1), tachycardia, and tachypnea were among the other signs. 
Figure 1. Santa Inês ewe with pelvic asymmetry, pendulous udder, cranially displaced udder and walking reluctance.

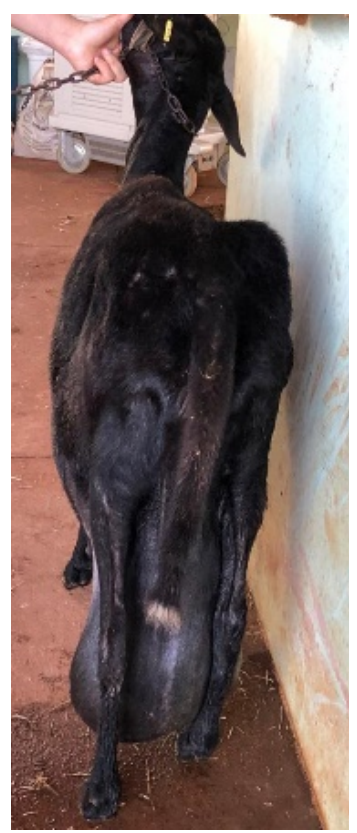

Source: Veterinary Hospital - UFLA (2019).

The blood test found normochromic normocytic anemia, absolute and relative neutrophils as well as relative lymphopenia. The urinalysis findings indicated the presence of ketone bodies.

The ewe was diagnosed with pregnancy toxemia and prepubic tendon rupture, based on clinical signs, anamnesis, and laboratory results.

\section{Discussion}

A similar clinical picture was reported by Turci et al. (2012) in a Santa Inês ewe, in which progressive weight loss by the end of the pregnancy was reported; she was carrying four fetuses. In the last weeks of pregnancy, the uterus is expected to increase in size and compress the rumen and reticulum, causing the animal to reduce food intake.

In order to treat the pregnancy toxemia, an enteral fluid therapy (5g $\mathrm{NaCl}, 20 \mathrm{~g}$ glucose, 4g $\mathrm{NaCHO} 3,1 \mathrm{~g} \mathrm{KCl}$ ) was continuously administered; 
propylene glycol $40 \mathrm{~mL}$, orally (VO), SID; vitamin B12, $500 \mathrm{mcg}$, intramuscular (IM), SID for three days; $40 \mathrm{~mL}$ of calcium gluconate, intravenous (IV) for two days; $100 \mathrm{~mL}$ of five percent glucose, IV, for three days. In addition to injectable glucose, the treatment focused on propylene glycol, administered orally, allowing thus a continuous and prolonged absorption. Calcium helped prevent ketosis, as a neoglycogenic precursor, and subclinical hypocalcemia. Vitamin B12 worked as an addition to glycogenesis from propionic acid as an attempt to stimulate the appetite.

Besides the clinical signs related to pregnancy toxemia, the patient's condition was similar to the ones reported by literature regarding prepubic tendon rupture (Image 2). However, as observed by Mather (1960), the animal, in this particular case, also presented subcutaneous edema, which extended from the udder to the xiphoid region, which may have occurred due to compression of the superficial and caudal epigastric veins that drain the abdomen, or due to muscle injury in the area surrounding the rupture (SEYREK-INTAS; KUMRU; SEYREK-INTAS, 2010), as well as a pendulous abdomen.

Figure 2. The pregnant Santa Inês ewe presenting pendulous abdomen, ventral edema and pendulous udder.

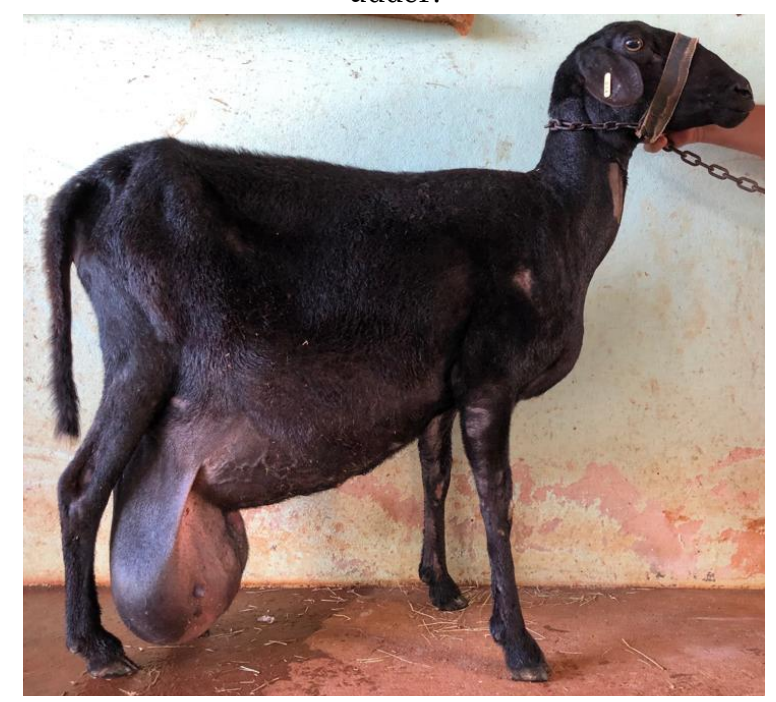

Source: Veterinary Hospital - UFLA (2019). 
The fact that prepubic tendon rupture in ruminants is less common when compared to mares may be attributed to the added support provided by the Symphyseal tendon. In small ruminants, prepubic tendon rupture is more complicated as it usually leads to injury of the udder due to the closeness of the udder to the ground, resulting in complications if not treated immediately (AL-ANI; KHAMAS, 2016).

In severe cases of prepubic tendon rupture, bilateral bleeding may occur in the abdominal muscles and subcutaneous tissue. When there is a lack of viability to the female or to the fetus, euthanasia is an alternative (JALIM, 2019; DAR et al., 2016).

Resting and abdominal support with bandages or commercial straps help to control the edema and the progression of the rupture, making abdominal tension more comfortable. (PERKINS; FRAZER, 1994). However, in this case, abdominal support wrap was not used because the udder was large and pendulous. Instead, the medication used was flunixin meglumine $(1,1 \mathrm{mg} / \mathrm{kg})$, intravenous, every 24 hours for three days for analgesia.

An ultrasound examination confirmed the viability of the two fetuses and no hernial content was observed. In a cautious approach, in the last days of pregnancy, when the due date is known, the induction of parturition in ewes can be performed with corticosteroids (SANTANA et al. 2010). After eight days of hospitalization, the labor was induced using a single dose of dexamethasone (20mg dose total), IM, as Prestes and Landim-Alvarenga (2017) recommend. The patient went into labor after three days of corticosteroid administration. Obstetric examination detected cervical mucus secretion and cervical dilation indicating the ewe was in labor. As it was expected, abdominal contractions were denied due to the absence of function of its prepubic tendon, therefore, obstetric maneuvers were conducted to remove the fetuses. The lambs were born in well developed, but large (3.8 kg and $4.8 \mathrm{~kg}$ ) relative to the breed standard (Image 3). 
Figure 3. The lamb was born large $(4,8 \mathrm{~kg})$ relative to the Saint Inês breed standard. This picture was taken seven days after its birth.

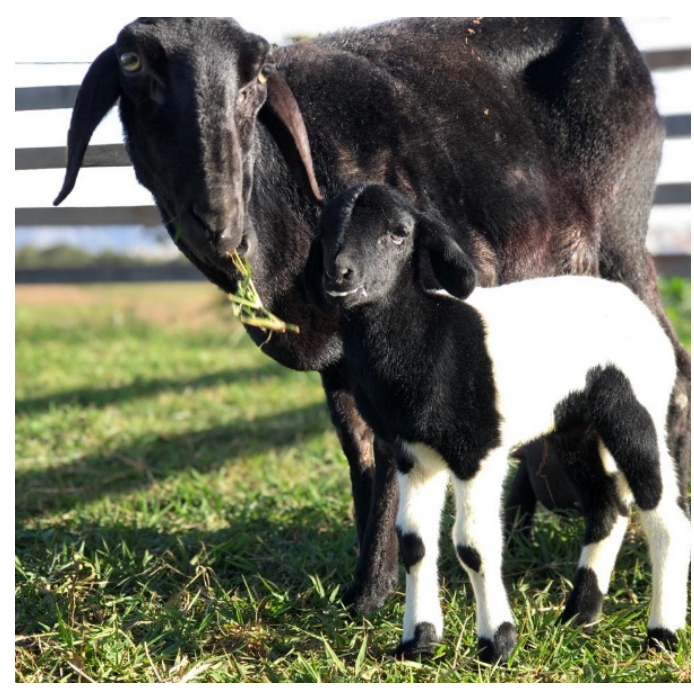

Source: Veterinary Hospital - UFLA (2019).

Clinical history was consistent with the diagnosis of prepubic tendon rupture. Clinical evaluation was essential to establish a definitive antemorten diagnosis. The prognosis was considered reserved regarding the animal's death. Prognostic of prepubic tendon rupture is serious, as most animals die during parturition (MONTEIRO et al., 2018), however any additional information that may help clarify this anatomical defect and future ability to conceive offers scientific support for treatment and to the appraisal of diagnostic accuracy of signs/symptoms that determine this condition.

The weight increase of the pregnant uterus on the abdominal floor, as well as the possible degenerative changes due to edema and weight, predispose to rupture. The prepubic tendon rupture of the assisted animal probably occurred due to these conditions. The best treatment must be offered so the patient is able to live a life without suffering or, when this is not possible, euthanasia should be performed to relieve the animal's suffering. Seventeen days after hospitalization, the ewe had no postpartum complications and was discharged. 


\section{Conclusion}

The report of this case works as an alert to the possibility of the occurrence of this affection in ewes and demonstrates the necessity of parturition assistance in these animals once the abdominal contractions are compromised. The diagnosis of this condition can be reached through clinical evaluation. Diagnostic imaging techniques are very useful and important for assessing the degree of tendon impairment, as well as to make a differential diagnosis of this affection with other causes of dystocia in ewes.

\section{Desmorrexia pré-púbica em ovelha Santa Inês - relato de caso}

Resumo: A ruptura do tendão pré-púbico resulta na perda do suporte do assoalho abdominal do animal. Uma ovelha, prenhe, da raça Santa Inês, de quatro anos, foi atendida com apatia e emagrecimento progressivo há dez dias e prolongamento da gestação. Ao exame clínico, verificou-se abdômen demasiadamente penduloso, discreto edema ventral entre o úbere e a região xifóide, úbere penduloso e com feridas, dificuldade de locomoção, assimetria de pelve, taquicardia e taquipneia. Detectou-se, na urinálise presença de corpos cetônicos. Foi confirmada à ultrassonografia, a viabilidade dos fetos. $\mathrm{O}$ parto foi induzido após oito dias de internação. Após três dias da aplicação do corticoide a ovelha entrou em trabalho de parto, sendo necessárias manobras obstétricas para retirada dos fetos, pois a mesma não apresentava contrações abdominais. O paciente se recuperou, mas como o quadro clínico era compatível com ruptura do tendão prépúbico, foi recomendado a retirada do animal da reprodução para evitar problemas futuros à ovelha $\mathrm{e}$ aos cordeiros. Conclui-se que o acompanhamento gestacional é indispensável para animais com esta afeç̧ão e que mediante avaliação clínica e ultrassonografia, pode-se chegar ao diagnóstico dessa afeç̧ão.

Palavras-chave: Ovino, Obstetrícia, Gestação, Ruptura de tendão prépúbico. 


\section{References}

AL-ANI, F. K.; KHAMAS, W. Ruptures of Prepubic Tendon in Shami (Damascus) Breed Pregnant Goats. Translational Biomed, v. 7, p. 2, 2016. DOI:10.21767/21720479.100074 .

BeitTenmilleR, M. R.; CONSTANTINESCU, G. M. Clinical anatomy and surgical repair of prepubic hernia in dogs and cats. Journal of the American Animal Hospital Association, v. 45, n. 6, p. 284-290, 2009. DOI: 10.5326/0450284.

DAR, K. H. et al. Surgical management of acquired prepubic hernia in ovines of Kashmir. The Indian Journal of Animal Sciences, v. 86, n. 10, p. 1148-1149. 2016.

GYAN, S.; PANDEY, S. K.; AHMAD, S. Q. Dystocia Due to Rupture of Prepubic Tendon in Mare. The Indian Veterinary Journal, v. 91, n. 03, p. 71-73, 2014. DOI: 10.1055/s-0038-1624614.

JALIM, S. L. Prepubic tendon rupture in the mare. Equine Veterinary Education, 2019. DOI: 10.1111/eve.12922.

MATHER, E. Rupture of the prepubic tendon in a Belgian mare associated with a hydrocephaloid foal. Iowa State University Veterinarian, v. 22, n. 2, p. 8, 1960.

MONTEIRO, G. A. et al. Pre-pubic tendon rupture in ewe. Veterinária e Zootecnia, v. 25 , n. 1, p. 1-12, 2018. DOI: 10.35172/rvz.2018.v25.39.

PERKINS, N. R.; FRAZER, G. S. Reproductive emergencies in the mare. Veterinary Clinics of North America: Equine Practice, v. 10, n. 3, p. 643-670, 1994. DOI: 10.1016/S0749-0739(17)30352-8.

PRESTES, N. C, LADIM-ALVARENGA, F. C. Obstetrícia veterinária. Rio de Janeiro: Guanabara Koogan, 2017. 
SANTANA, A. F. et al. Indução do parto em ovelhas da raça Santa Inês utilizando diferentes concentrações de dexametasona. PubVet, Londrina, v. 4, n. 3, ed. 108, art. 728, 2010. DOI: 10.1590/1678-5150-pvb-6210.

SEYREK-INTAS, K.; KUMRU, I. H; INTAS, D. SEYREK. Rupture of the prepubic tendon in a congenitally lordotic mare. Tierärztl Prax Grobtiere, v. 39, p. 46-48, 2011. DOI: $10.1055 / \mathrm{s}-0038-1624614$.

TURCI, R. C. et al. Toxemia da prenhez relacionada à gestação múltipla patológica em ovelhas. Centro científico conhecer, v. 30, n. 11, p. 1607- 1613, 2012. 